\title{
PENERAPAN E-COMMERCE DENGAN STRATEGI BUSINESS MODEL CANVAS (BMC) UNTUK PENJUALAN SPAREPART MOTOR
}

\author{
Tezza Ermuda Nugroho ${ }^{1}$, Yuliazmi $^{2}$ \\ ${ }^{1,2}$ Fakultas Teknologi Informasi, Sistem Informasi , Universitas Budi Luhur, Jakarta, Indonesia \\ Email: ${ }^{1}$ tezza.wae@gmail.com, ${ }^{2}$ yuliazmi@budiluhur.ac.id
}

\begin{abstract}
Abstrak-Seiring berjalannya waktu, teknologi yang semakin berkembang memungkinkan kita untuk dapat berkomunikasi, mendapatkan informasi hingga bertransaksi seperti di E-Commerce melalui internet. Toko Yon Kawasaki Part adalah contohnya, toko yang menjual suku cadang original kawasaki ini sudah menggunakan E-commerce. Namun biaya promosi untuk menaikan rating toko dan menaikan produk yang dijual dirasa terlalu berat, ditambah situasi sekarang saat pandemi orang akan jarang datang langsung ke toko untuk membeli produk mengakibatkan penjualan semakin menurun. Juga dalam melakukan transaksi di E-Commerce pada umumnya dana akan disimpan terlebih dahulu oleh pihak E-Commerce, Jika barang sudah diterima oleh pembeli barulah uang akan dikirim ke toko, hal itu mengakibatkan akan memakan waktu untuk membeli stok produk pada toko Yon Kawasaki Part. Dalam penelitian ini, penulis akan membuat website e-commerce dengan menggunakan Content Management System (CMS). Penulis juga akan menggunakan strategi bisnis Business Model Canvas (BMC) dan memberikan strategi dan teknik dalam pemasaran dengan menggunakan teknik Search Engine Optimization (SEO) untuk menaikan website E-Commerce pada mesin pencarian. Juga memanfaatkan media sosial sebagai media pemasaran dan informasi untuk menjangkau seluruh pengguna media sosial tersebut. Kesimpulan dalam melakukan penelitian ini adalah dengan dibuatkannya website toko online e-commerce ini diharapkan mampu menekan biaya promosi, juga dengan memanfaatkan strategi marketing SEO dapat membantu promosi, dan pemilik tak perlu menunggu waktu lama untuk mencairkan dana.
\end{abstract}

Kata Kunci: E-Commerce, Suku Cadang, Bussines Model Canvas (BMC), Search Engine Optimization (SEO), Content Management Sistem (CMS).

\begin{abstract}
Along with time, technology that is keep developing allows us to be able to communicate, from getting information to doing transaction in E-Commerce in the internet. Yon Kawasaki Part Store is one of example, the store that sell original spare parts of kawasaki already using E-Commerce. But the ads price for increasing the store and product ratings is too expensive, and with the pandemic situation right now people barely come to the store to buy product which make the sell keep decrease. Also when we doing transaction in E-Commerce mostly the money will be hold by the E-Commerce, if the buyer already have the product the money will be transfered to the store, it make take some times to buy product from Yon Kawasaki Part Store. In this research, author will make E-Commerce online shop using Content Management System (CMS) from Wordpress. Author also using business strategy using Business Model Canvas (BMC) Method, and provide a marketing strategy by using Search Engine Optimization (SEO) method to make the E-Commerce website to the top in search engine. Also utilizing social media as a marketing and information media to reach out all the social media user. The conclusion of this research is with the E-Commerce website to be expected to able decrease the promotion price, also with using marketing SEO strategy will help promotion, and the owner will no longer need to take a lot of time to cash out..
\end{abstract}

Keywords: E-Commerce , Bussines Model Canvas (BMC), Search Engine Optimization (SEO), Content Management Sistem (CMS), Sparepart.

\section{PENDAhUluan}

Dengan kemajuan teknologi yang berkembang sangat pesat saat ini, kebutuhan manusia juga semakin meningkat. Teknologi adalah salah satu kebutuhan dalam kehidupan manusia saat ini, begitupun dengan internet yang sekarang hampir dipakai oleh semua orang setiap harinya, ini memungkinkan orang - orang untuk melakukan transaksi dengan mudah menggunakan $e$-commerce untuk melakukan jual beli [1]. Sekarang untuk melakukan jual beli tidak perlu lagi dilakukan secara langsung dengan mendatangi toko seperti pada seperti dahulu kala. Antara penjual maupun pembeli menggunakan e-commerce adalah cara yang efektif untuk melakukan pemasaran dan promosi dibandingkan dengan membuka toko secara fisik. [2].

Namun dengan adanya pandemi wabah penyakit COVID-19 yang tengah menyerang seluruh dunia, terkhususnya di negara kita Indonesia ini. Pemerintah memberlakukan gerakan "Di Rumah Aja” yang membuat konsumen tidak dianjurkan keluar rumah dan tidak bisa berbelanja berbagai macam kebutuhan secara langsung ke toko. di tengah wabah virus ini, e-commerce dapat diandalkan sekali karena tidak perlu lagi datang ke toko yang ingin di tuju untuk membeli kebutuhan, karena dengan adanya e-commerce memungkinkan kita untuk belanja kebutuhan hanya dari rumah hanya dengan menggunakan perangkat yang tersambung dengan internet [3].

Yon Kawasaki Part contohnya, toko yang menjual suku cadang motor khusus merk Kawasaki. Toko ini berdomisili di daerah Jakarta Barat tepatnya di Palmerah. Toko ini sudah menggunakan e-commerce pihak ketiga 
namun beban biaya yang harus dikeluarkan untuk menaikan rating toko dirasa berat oleh pemilik toko ditambah dampak dari pandemi ini semakin membebankan karena sepi pengunjung yang datang langsung ke toko.

Sebagai salah satu solusi menjawab masalah tersebut, penulis memberikan solusi dengan membuatkan sebuah sistem penjual yang berbasis website dengan konsep toko online (e-commerce) untuk memudahkan konsumen berbelanja secara online dengan baik juga memberikan strategi pemasaran agar pemilik tidak bergantung pada $e$-commerce pihak ketiga yang memberatkan biaya dibandingkan memiliki website e-commerce sendiri.

Penulis telah melakukan studi literatur yang berhubungan dengan penelitian ini sebagai acuan, berikut ringkasannya : penelitian [4] dengan judul "Implementasi Sistem E-Commerce pada Guna Motor Berbasis Content Management System Wordpress" menjelaskan tentang badan usaha Guna Motor yang melakukan kegiatan penjualan aksesoris untuk mobil dan juga suku cadang dengan menggunakan cara yang masih sederhana dalam bertransaksi maupun mengelola data baik itu stok atau rekapitulasi penjualan. Dalam menjalankan usahanya tersebut terdapat berbagai macam masalah yang timbul seperti kesulitan melihat stok barang, penyimpanan dokumen yang sembarangan, kesulitan untuk melakukan promosi dan sulit untuk melihat pesanan pelanggan. Itu semua mengakibatkan proses transaksi terhambat, oleh karena itu dibuatkannya aplikasi toko daring (online) seperti e-commerce sebagai sarana untuk melakukan promosi dan penjualan. Penelitian ini juga memanfaatkan juga strategi SEO on page yang akan meningkatkan page rating dalam e-commerce tersebut dibantu dengan Business Model Canvas. Dengan adanya e-commerce tersebut dapat mempermudah proses transaksi, adanya laporan stok barang, dan promosi melalui instagram untuk menarik pembeli.

Penelitian [5] yang berjudul "Implementasi Website Berbasis Search Engine Optimization (SEO) Sebagai Media Promosi" meneliti pada bisnis perusahaan yang berfokus pada jasa photography, yaitu Snap Art Photography. Promosi yang mereka lakukan masih bersifat sangat tradisional, biaya yang dikeluarkan untuk sebuah promosi iklan sangat berat belum lagi profit yang dihasilkan tidak sesuai juga target pasar yang cakupannya sangat kecil. Agar dapat menyelesaikan berbagai masalah tadi, teknologi internet sanganatlah berguna dengan membuatkan website dan menggunakan teknik SEO pada perusahaan ini terbukti dapat meningkatkan penjualan semakin naik dan target pada pemasaran terlihat lebih menjangkau lebih luas. Berikut teknik-teknik SEO yang digunakan seperti Tittle tags, meta keyword, meta description, heading tag, url structure dan lain-lain. Hasilnya website tadi pada awalnya tidak ter-index telah berhasil menaik ke urutan pertama pada halaman mesin pencari Google dan mendapatkan trafic visitor dari mesin pencarian Google.

Penelitian [6] dengan judul "Perancangan E-Commerce Untuk Penjualan Spareparts pada bengkel ABM Motor" meneliti tentang ABM Motor yang memiliki masalah yaitu bukti transaksi penjualan hanya berupa catatan pada buku sehingga kurang efisien dalam penyimpanan, tidak adanya informasi tentang stok barang, sehingga pemilik sering mengalami kesulitan dan keterlambatan dalam memberikan informasi stok barang, tidak adanya informasi rekapitulasi barang, sehingga pemilik sulit menentukan sparepart mana yang paling banyak terjual setiap bulannya. Tujuan pada penelitian kali ini adalah membuatkan suatu aplikasi sistem informasi berbasis daring penjualan sparepart dengan konsep e-commerce dengan mengandalkan teknik analisis Business Model Canvas (BMC). Sebagai bagian dari pemecahan masalah penjualan sparepart pada Bengkel ABM Motor. Manfaat penelitian ini adalah Bagi Pemilik Bengkel: Dapat mengontrol dengan mudah transaksi penjualan sparepart dan jasa service motor dan menghasilkan laporan penjualan dan jasa service yang lebih cepat, tepat, dan akurat. Bagi pihak customer : mempermudah proses transaksi dan mengurangi keterlambatan dalam menerima informasi penjualan sparepart motor. Hasil penelitian yang penulis tuliskan pada penelitian ini menyimpulkan tentang bengkel ABM Motor yaitu: Dengan dibuatkannya sebuah sistem e-commerce penjualan pada Bengkel ABM Motor pelanggan tidak perlu datang ke bengkel untuk membeli suku cadang, selain untuk menaikan tingkat penjualan sistem ini juga untuk menghitung stok dan pendapatan secara otomatis.

\section{METODE PENELITIAN}

Metode penelitian merupakan langkah urutan yang dijalankan oleh penulis meliputi tahap awal hingga tahap akhir pelaksanaan penelitian, dan merupakan bagian penting dari penelitian yang mempengaruhi hasil dari penelitian. Metode penelitian yang dilakukan peneliti dapat dilihat pada Gambar 1 . 


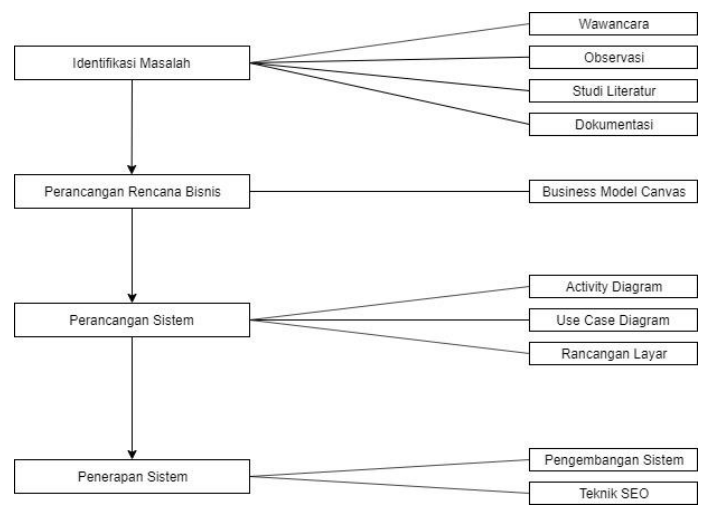

Gambar 1. Metode Penelitian

\subsection{Identifikasi Masalah}

Dalam penelitian ini identifikasi masalah sangat dibutuhkan untuk mengetahui masalah yang sedang dihadapi, untuk mengetahui masalah-masalah tersebut penulis menggunakan teknik pengumpulan data untuk merancang dan membangun sistem, berikut metode yang digunakan dalam teknik pengumpulan data :

a. Wawancara

Metode pengumpulan data ini menggunakan cara tatap muka secara langsung maupun daring dan melakukan tanya jawab antara 2 pihak, pihak pertama sebagai pewawancara dan pihak kedua sebagai narasumber. Disini terjadilah proses tanya jawab untuk mengumpulkan data.

b. Observasi

Merupakan metode pengumpulan data dengan cara mengamati objek penelitian secara seksama kegiatan yang dilakukan oleh tempat riset sehari-hari, kemudian menarik kesimpulan dari pengamatan yag dilakukan.

c. Dokumentasi

Dalam pengumpulan data ini dilakukan adalah mengumpulkan dan menganalisis dokumen yang didapatkan dalam tempat riset yang berkaitan dengan topik yang sedang dibahas.

d. Studi Literatur.

Metode ini adalah untuk mencari referensi teori yang berkaitan dengan topik yang dibahas, yang bertujuan untuk memperkuat teori dan sebagai acuan untuk melakukan penelitian.

\subsection{Perancangan Rencana Bisnis}

Dalam mengembangkan sistem E-commerce ini, penulis menggunakan metode Business Model Canvas (BMC) untuk mengembangkan bisnis dari Yon Kawasaki Part dan menganalisis strategi bisnis yang akan digunakan dalam pembuatan sistem ini.

Business Model Canvas (BMC) bertujuan untuk membantu perusahaan merancang perencanaan proses bisnis dan menetapkan serta memvalidasi poin penting dalam bisnis seperti; sumber daya, aktivitas, hubungan yang akan dijalin dengan pihak terkait, pendapatan, hingga pengeluaran yang harus dikeluarkan.

Terdapat 9 pilar utama yang menjadi landasan dalam menggunakan strategi Business Model Canvas (BMC), yaitu : customer segments, value propositions, channels, customer relationship, revenue streams, key resources, key activities, key partnership dan cost structure.

\subsection{Perancangan Sistem}

Dalam Perancangan sistem E-Commerce pada Yon Kawasaki Part, penulis menggunakan tools UML (Unified Modelling Language) yang berisikan :

a. Activity Diagram.

Diagram ini digunakan untuk mendeskripsikan proses bisnis dari awal sampai akhir secara berurutan.

b. Use Case Diagram.

Diagram ini berguna untuk mendeskripsikan tipe interaksi antara user sebuah sistem dengan sistemnya sendiri bagaimana sebuah sistem dipakai.

e. Rancangan Layar.

Tampilan antarmuka/visual dari sebuah website yang dibuat ditujukan untuk user. 


\subsection{Penerapan Sistem}

Dalam melakukan penerapan sistem ini penulis memberikan gambaran tentang seperti apa sistem usulan yang dibuat untuk user terhadap sistem usulan pada Yon Kawasaki Part ini, berikut beberapa hal yang penulis lakukan dalam tahap penerapan ini :

a. Pengembangan Sistem.

Untuk mengembangkan sebuah sistem website E-Commerce yang dilakukan pada penelitian ini menggunakan Content Management System (CMS) yang disediakan oleh Wordpress, Pembelian Hosting dan Domain ini harus dilakukan agar sistem usulan website E-Commerce ini dapat berjalan secara online dan bisa di buka dimanapun dan kapanpun, juga memiliki alamat sendiri untuk website tersebut dan juga melakukan pengujian sebelum di gunakan, pengujian dilakukan oleh penulis dan user.

b. Teknik SEO.

Dalam penelitian ini teknik Search Engine Optimization (SEO) ini pada pembuatan sistem usulan ini berguna untuk meningkatkan kunjungan pada website untuk memperluas informasi tentang produk yang dijual, dan website akan tampil dalam halaman teratas pada mesin pencarian.

\section{HASIL DAN PEMBAHASAN}

\subsection{Business Model Canvas}

Business Model Canvas (BMC) merupakan strategi atau rencana bisnis untuk mengatur segala urusan terkait perusahaan agar jelas dan terarah seperti rencana pengeluaran, aktivitas, rekan bisnis, target pasar, dll [7]. Business model canvas pada toko Yon Kawasaki Part bisa dilihat pada Gambar 2.

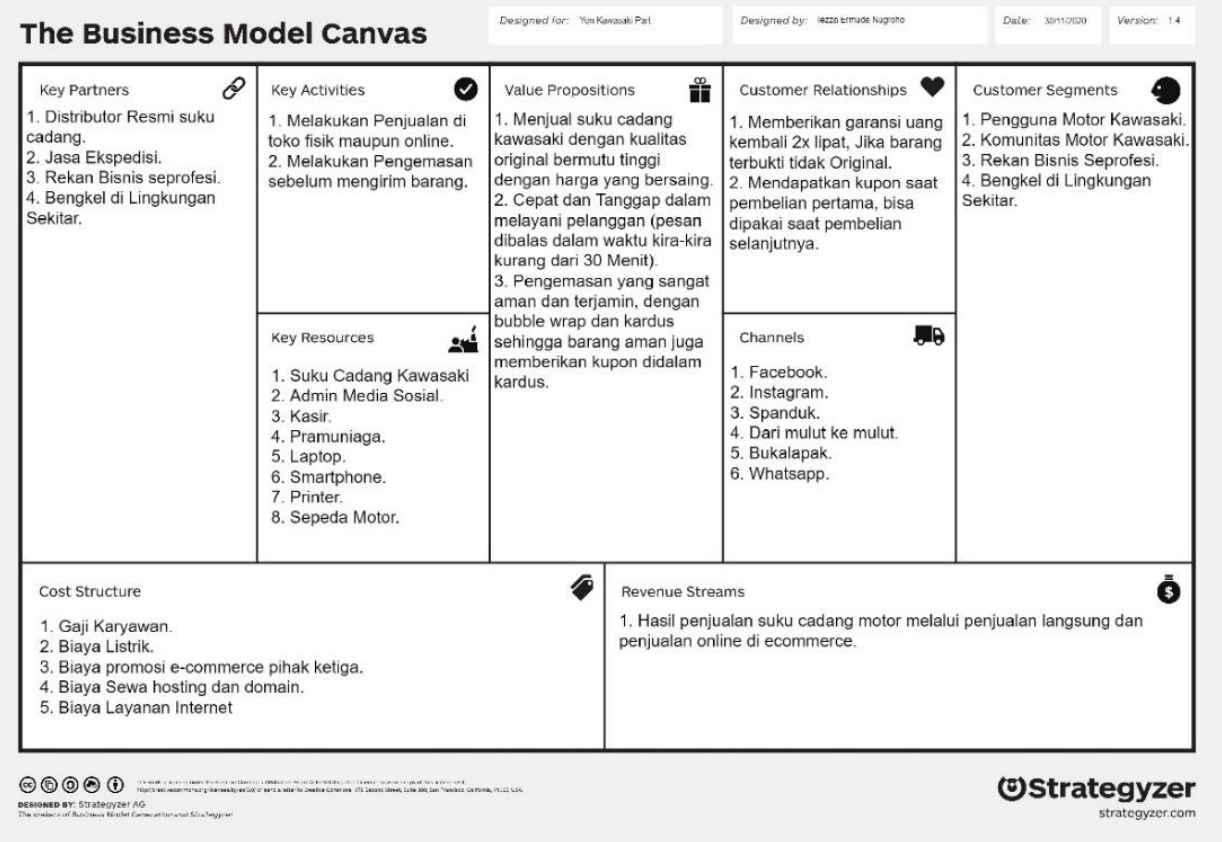

Gambar 2. Business Model Canvas Yon Kasawaski Part

Komponen-komponen business model canvas beserta deskripsinya yang telah di analisis pada toko Yon Kawasaki Part :

a. Value Propotition merupakan keunggulan bisnis dari toko Yon Kawasaki Part yang menjadi nilai jual dalam menjual produknya yaitu berupa jaminan suku cadang kawasaki dengan kualitas original bermutu tinggi dengan harga bersaing, Cepat dan tanggap dalam melayani pembeli (pesan dibalas dalam waktu kira-kira kurang dari 30 menit) dan pengemasan yang sangat aman dan terjamin, dengan bubble wrap dan kardus sehingga barang aman juga memberikan kupon didalam kardus.

b. Customer Segment merupakan tujuan utama dalam target fokus pada penjualan dan mempromosikan Yon Kawasaki Part. Target bisnis dari Yon Kawasaki Part adalah pengguna motor kawasaki, komunitas motor kawasaki, rekan bisnis seprofesi dan bengkel di lingkungan sekitar. 
c. Channel merupakan sebuah strategi marketing yang akan dilakukan dalam menjalankan bisnis berupa promosi dari berbagai macam target, seperti Facebook, Instagram, Spanduk, Mulut ke mulut, Bukalapak, Whatsapp.

d. Customer Relatonships merupakan cara mempertahankan pembeli agar nyaman dan mungkinkan pembeli untuk membeli barang kembali di Yon Kawasaki Part. Hal tersebut dilakukan Yon Kawasaki Part dengan memberikan garansi jika barang yang dibeli dari Yon Kawasaki Part bukan barang asli maka uang kembali 2x lipat, dan pembeli akan mendapatkan kupon saat membeli produk untuk pertama kalinya, kupon bisa dipakai saat melakukan pembelian selanjutnya.

e. Revenue Stream merupakan sumber dari pendapatan usaha yang dilakukan oleh Yon Kawasaki Part, yaitu dari hasil penjualan suku cadang motor kawasaki melalui penjualan langsung dan penjualan online di e-commerce.

f. Key Activities merupakan kegiatan yang dilakukan dalam menjalankan usaha bisnis tersebut seperti berjualan di toko offline dan berjualan online juga melakukan packaging sebelum mengirim barang.

g. Key Resource merupakan sumber daya yang dimiliki oleh Yon Kawasaki Part dalam menjalankan usaha baik sumber daya manusia maupun alat yang digunakan seperti produk yang dijual yaitu suku cadang kawasaki, admin media sosial, pramuniaga, kasir, laptop, smartphone, printer, sepeda motor.

h. Key Partners merupakan partner bisnis atau mitra bisnis yang akan membantu kita dalam melakukan usaha bisnis yang dijalankan, seperti distributor suku cadang, jasa ekspedisi, rekan bisnis seprofesi, dan bengkel di sekitar lingkungan.

i. Cost Structure merupakan pengeluaran uang dari bisnis yang dijalankan Yon Kawasaki Part, seperti biaya listrik, gaji karyawan, biaya promosi E-Commerce pihak ketiga, biaya sewa hosting dan domain serta biaya layanan internet.

\subsection{Proses Bisnis Usulan}

Activity diagram adalah urutan tahapan kegiatan aliran fungsionalitas dalam sebuah sistem. Pada tahap ini diagaram activity dapat digunakan untuk menunjukkan business workflow [8].

a. Activity diagram proses pemesanan produk

Activity Diagram ini menerangkan tentang proses memesan produk yang dilakukan oleh pembeli dengan masuk ke website toko kemudian memilih barang yang sesuai dengan keinginan pembeli lalu masukan kedalam keranjang setelah itu sistem akan jumlah dan harga produk dan lanjut ke menu check out, disini pembeli diminta mengisi form untuk pengiriman dan mentransfer sejumlah uang jika sudah pembeli menekan tombol buat pesanan lalu sistem akan menyimpan data dan memberikan arahan apa yang harus dilakukan pembeli, setelah itu pembeli melihat detail pesanan pada halaman akun saya. Activity diagram pada proses pemesanan produk bisa dilihat pada Gambar 3.

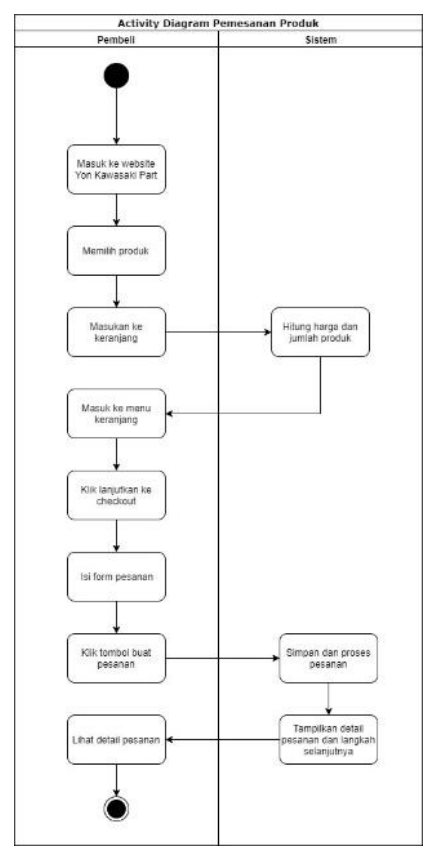

Gambar 3. Activity Diagram Proses Pemesanan Produk 
b. Activity diagram proses pembayaran produk dan konfirmasi bayar

Activity Diagram ini menjelaskan tentang proses setelah pembeli mentransfer sejumlah uang ke rekening toko maka pembeli masuk ke website dan kemudian menuju menu konfirmasi pembayaran, selepas itu pembeli mengisi form konfirmasi pembayaran sesuai dengan data pesanan. Lalu admin akan melakukan verifikasi pembayaran jika tidak sesuai akan menolak konfirmasi pembayaran sehabis itu pembeli diminta untuk mengisi kembali form dengan benar, jika sesuai maka admin akan langsung mengubah status dan akan memproses pesanan tersebut. Activity diagram proses pembayaran produk dan konfirmasi bayar bisa dilihat pada Gambar 4.

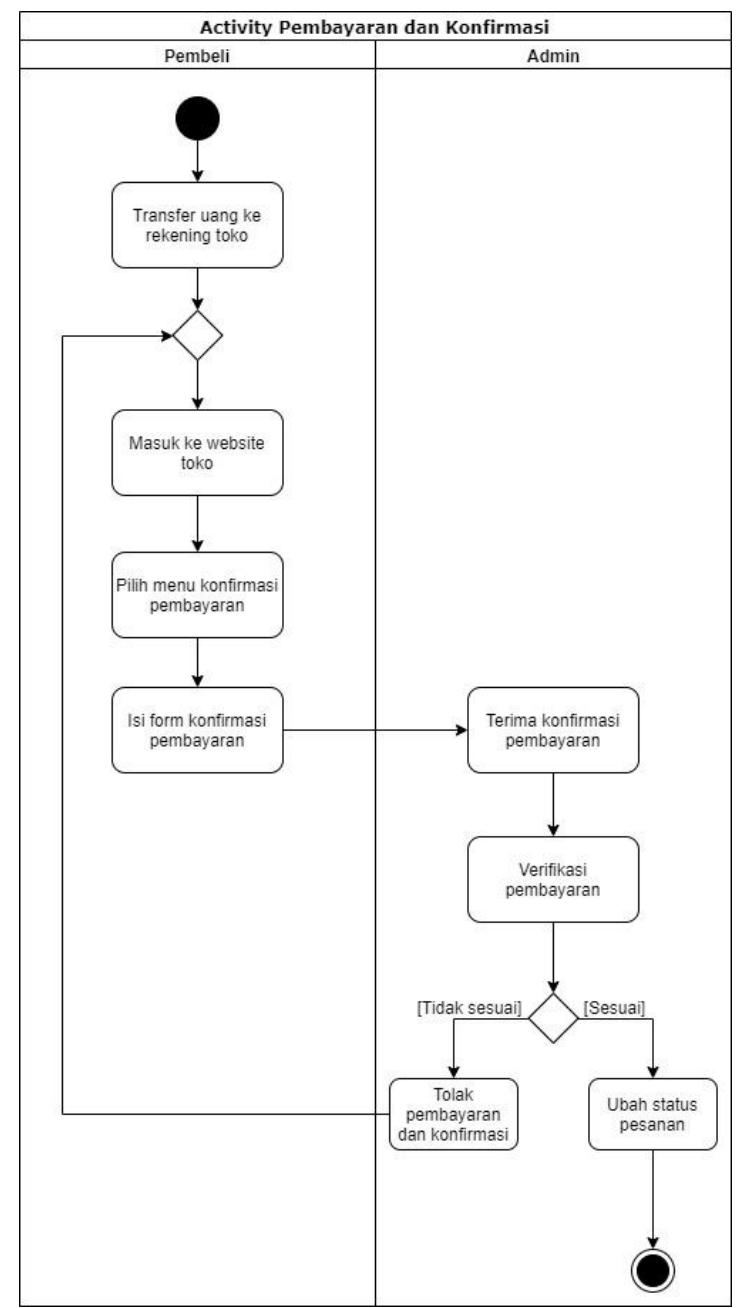

Gambar 4. Activity Diagram Proses Pembayaran Produk

\subsection{Use Case Diagram}

Use Case diagram merupakan sebuah gambar yang menunjukan seorang aktor dengan aktor lainnya dan apa saja yang dapat dilakukan oleh aktor tersebut pada sebuah sistem [9]. Use case diagram yang di implementasi pada website Yon Kawasaki Part terdiri dari 2 aktor saja admin dan pembeli yang akan melakukan interaksi dengan sistem, seperti admin yang mencetak berbagai macam laporan, melakukan verifikasi pembayaran, verifikasi pengembalian dana, mengirim resi dan pembeli yang melakukan transaksi seperti membuat pesanan, tambah wishlist produk, konfirmasi pembayaran, melihat status pesanan, pengembalian produk, lalu menerima berbagai macam notifikasi seperti : notifikasi pembelian produk, notifikasi pesanan diproses, notifikasi pengiriman resi, notifikasi pesanan selesai, notifikasi pengembalian dana, notifikasi konfirmasi pembayaran, notifikasi pengembalian produk dan notifikasi pesanan batal. Use case diagram pada website yang di implementasi toko Yon Kawasaki part bisa dilihat pada Gambar 5. 

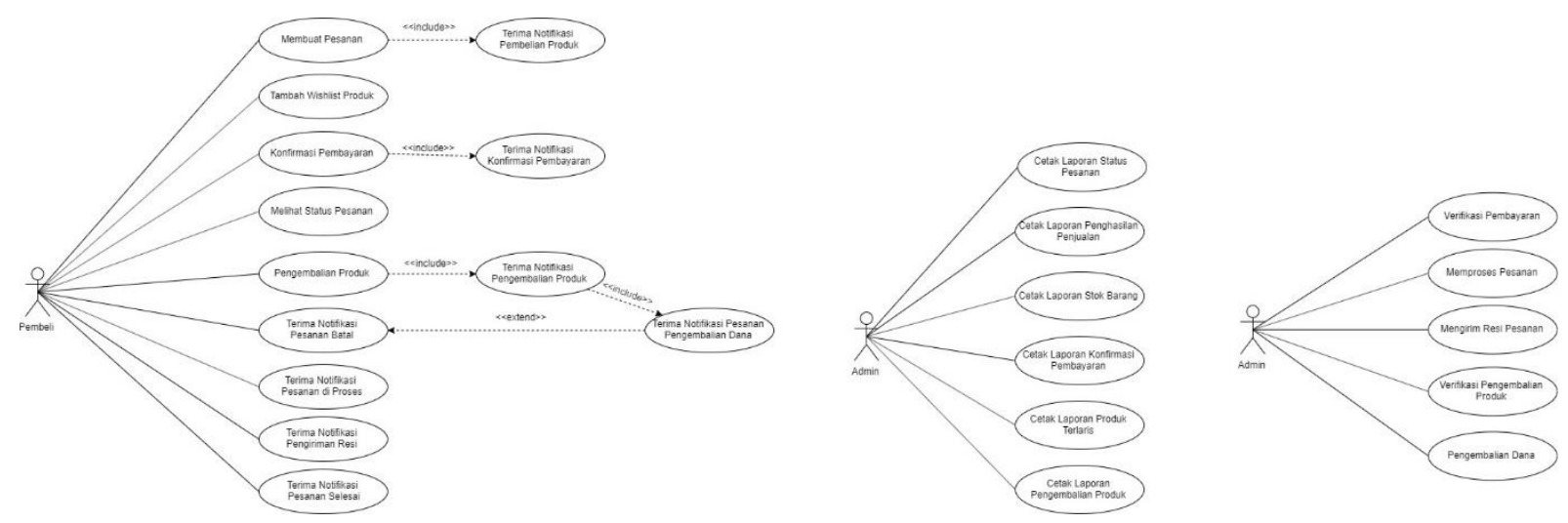

Gambar 5. Use Case Diagram Yon Kawasaki Part

\subsection{Rancangan Layar}

Rancangan layar adalah sebuah purwarupa dari desain pada tampilan awal sebuah sistem atau bisa disebut sebagai user interface [10].

a. Rancangan layar beranda

Rancangan layar beranda ini menggambarkan tampilan halaman awal pada website berisi tampilan yang menarik dan beberapa produk agar menarik pembeli. Rancangan layar beranda bisa dilihat pada Gambar 6 .

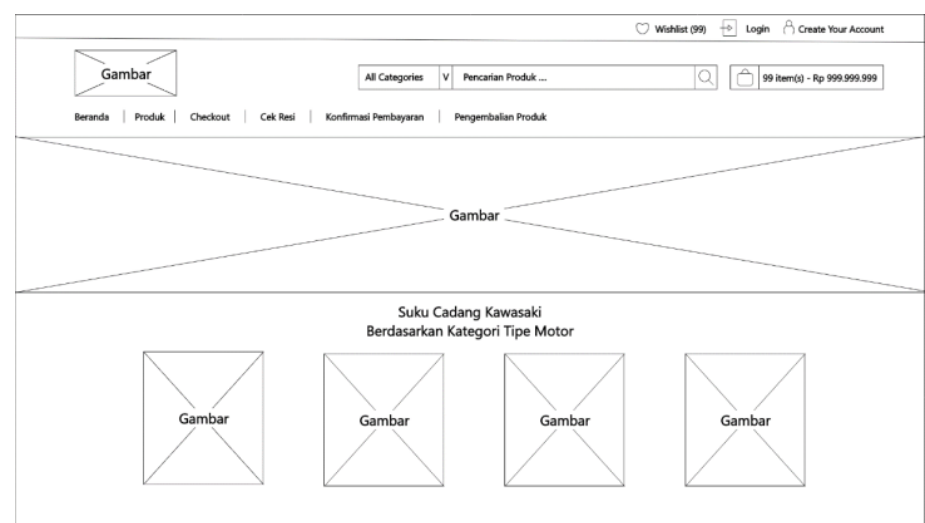

Gambar 6. Rancangan Layar Beranda Yon Kawasaki Part

b. Rancangan layar keranjang

Rancangan layer checkout ini tampilan pada halaman keranjang pada saat pembeli sudah menambahkan produk kedalam keranjang. Rancangan layar checkout bisa dilihat pada Gambar 7.

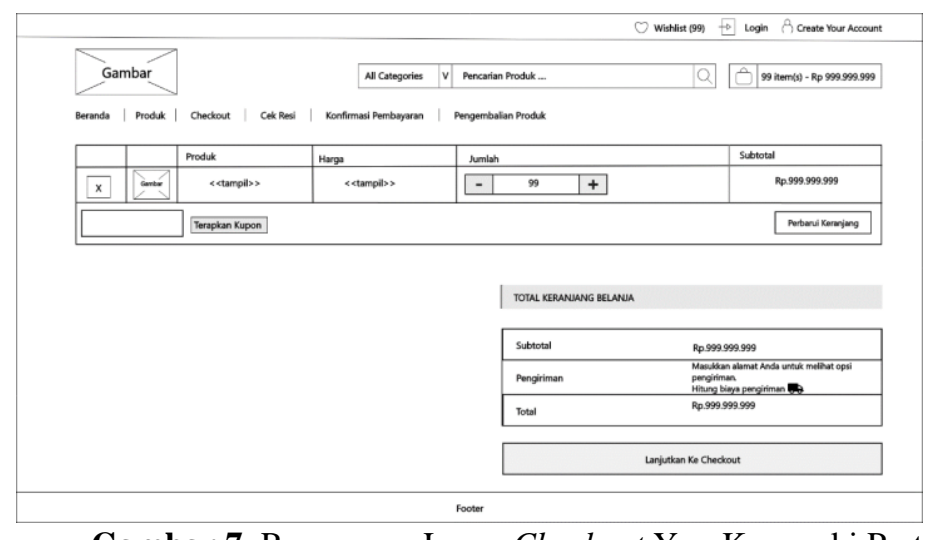

Gambar 7. Rancangan Layar Checkout Yon Kawasaki Part 


\subsection{Penerapan Sistem}

Model sistem website E-Commerce dengan menggunakan Content Management System (CMS) pada toko Yon Kawasaki Part yang telah diterapkan pada halaman website www.yonkawasakipart.com. Berikut tampilannya dapat dilihat pada Gambar 8.
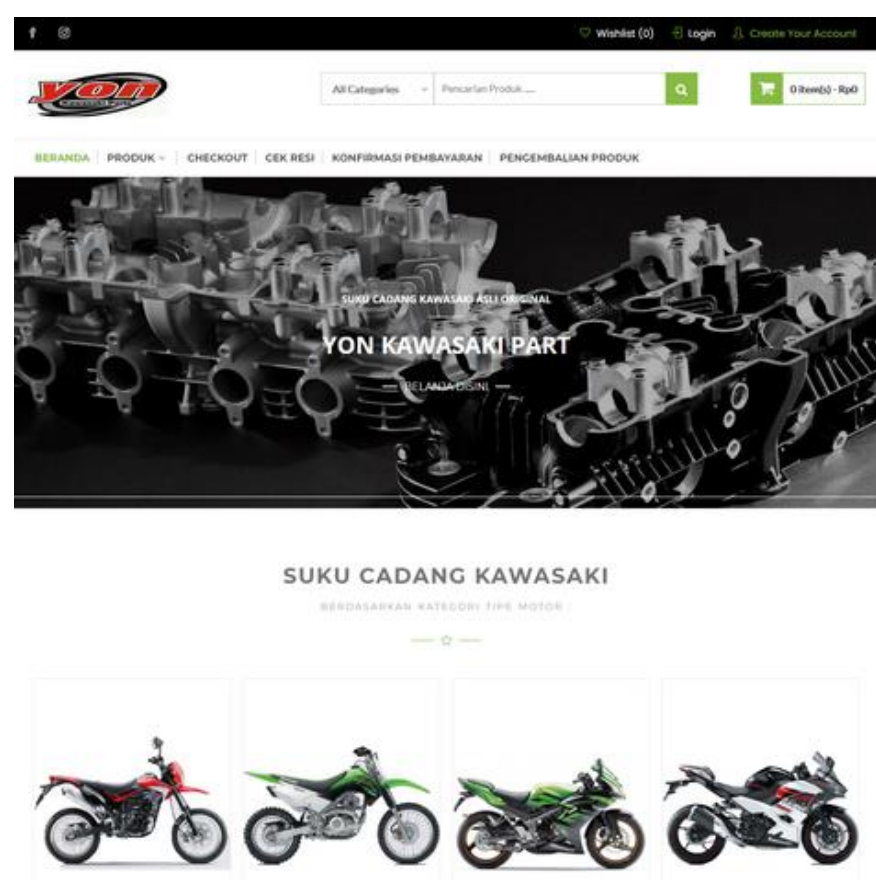

Gambar 8. Tampilan website E-Commerce Yon Kawasaki Part

\subsection{Teknik Strategi Search Engine Optimization (SEO)}

Search Engine Optimization (SEO) merupakan cara untuk menaikan rating pada website agar menjadikan posisi halaman website tersebut menjadi teratas pada mesin pencarian dan pembeli semakin mudah untuk menuju website tersebut [11]. Berikut ini adalah langkah-langkah untuk mengoptimasi SEO dengan menggunakan tools Yoast SEO pada website toko Yon Kawasaki Part :

a. Menambahkan kata kunci dan meta deskripsi yang sesuai dengan produk maka akan membantu mesin pencari dalam proses SEO dan muncul pada mesin pencari tersebut. Kata kunci haruslah sesuai dengan judul produk yang akan dijual dan mengandung kata yang banyak dicari di mesin pencari. Sedangkan, meta deskripsi adalah gambaran singkat mengenai produk tersebut dengan bahasa yang singkat namun mudah dimengerti, ini bisa dilihat pada Gambar 9. 


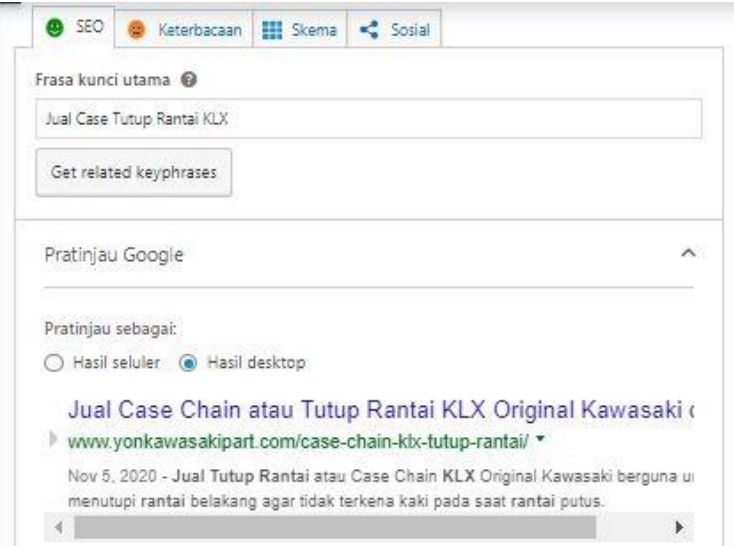

\begin{tabular}{l} 
Judul SEO \\
Jual Case Chain atau Tutup Rantai KLX Original Kawasaki di jakarta Pernisah \\
Judul situs \\
Slug \\
Case-chain-klx-tutup-rantai \\
Juakripsi meta Tutup Rantai atau Case Chain KLX Original Kawasaki berguna untuk menutupi \\
rantai belakang agar tidak terkena kaki pada saat rantai putus. \\
\hline Analisis SEO \\
Jual Case Tutup Rantai KLX
\end{tabular}

Gambar 9. Kata Kunci Penelusuran, Judul SEO, Slug, dan Deskripsi Meta

b. Hasil penelusuran penggunaan strategi SEO yang diimplementasikan pada penelitian ini. Hasil penelusuran tersebut didapatkan pada halaman pertama pada mesin pencari Google pada tanggal 30 Januari dan bisa dilihat pada Gambar 10.
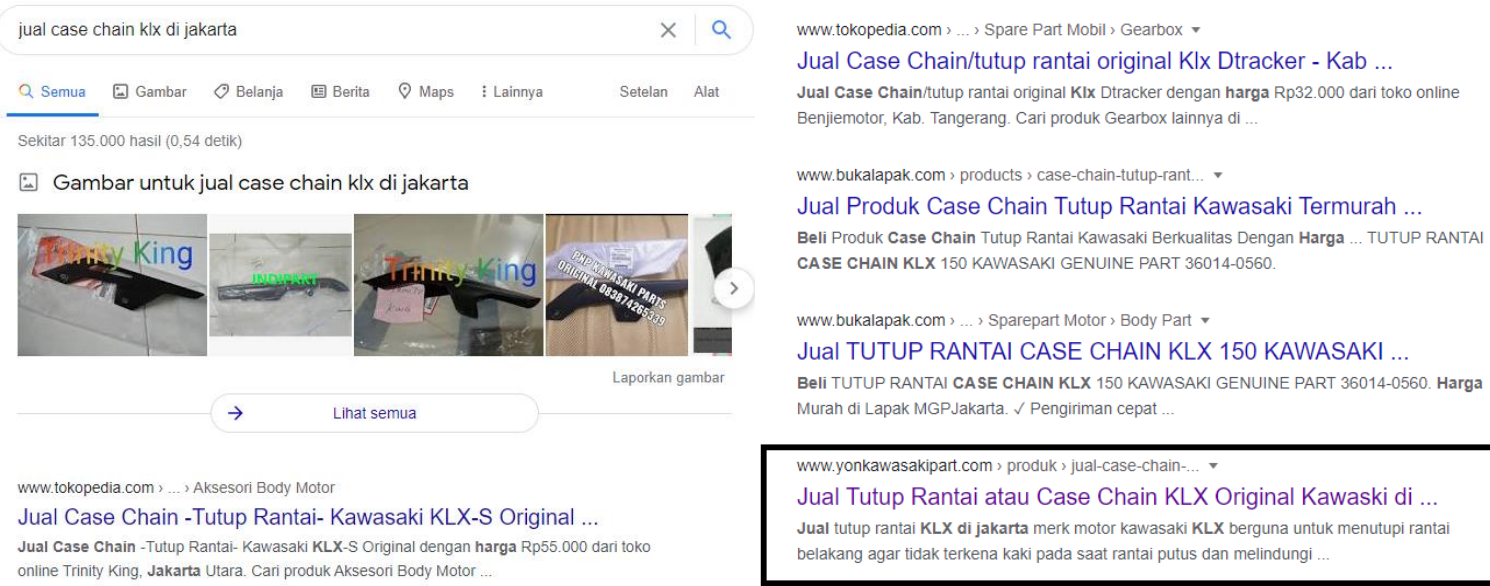

Gambar 10. Penelusuran hasil teknik $S E O$ pada mesin pencari Google

\subsection{Strategi Pemasaran}

Strategi pemasaran merupakan sebuah teknik untuk membantu menaikan jumlah pelanggan dengan melakukan promosi yang tepat sasaran dan dapat menjangkau sejauh mungkin kepada pembeli [12]. Strategi pemasaran yang akan digunakan toko Yon Kawasaki Part adalah dengan menggunakan website akan meningkatkan penjualan, yaitu dengan rajin menambah produk baru dan meningkatkan kualitas pada konten website. Dengan begitu pembeli akan semakin percaya dengan website Yon Kawasaki Part. Website Yon Kawasaki Part : https://yonkawasakipart.com/ serta menggunakan media sosial dapat menjangkau lebih banyak pembeli. Media sosial juga dapat diaplikasikan sebagai sarana untuk memberikan informasi terbaru dan menarik seperti promo menarik dan diskon. Media sosial Yon Kawasaki Part yaitu :

a. Facebook : https://facebook.com/yonkawasakipart.

b. Instagram : https://instagram.com/yonkawasakipartofficial.

\section{KESIMPULAN}

Kesimpulan analisis dan penelitian yang telah dilakukan, penulis membangun Sistem Website E-Commerce untuk toko online Yon Kawasaki Part maka penulis bisa menyimpulkan beberapa poin sebagai berikut, yaitu : hadirnya website e-commerce ini mampu menekan biaya promosi dalam penggunaan e-commerce pihak ketiga, penerapan strategi marketing dan SEO pada Yon Kawasaki Part dapat membantu proses promosi, dan terakhir pemilik tidak perlu menunggu lama untuk mencairkan uang pada saat menjual produk karena menggunakan metode transfer langsung. 


\section{DAFTAR PUSTAKA}

[1] A. Ujianti and G. Triyono, "Penerapan Website E-Commerce berbasis Content Management System (CMS) untuk Pelayanan Penjualan pada MSFashioners," Idealis, vol. 3, no. 1, pp. 436-442, 2020.

[2] S. Permoni and A. Ariesta, "PENJUALAN ONLINE PADA TOKO FRIEND SHOES JKT," pp. 244-251, 2019.

[3] Sudaryono, E. Rahwanto, and R. Komala, "E-commerce Dorong Perekonomian Indonesia, selama Pandemi Covid-19," J. Manaj. Bisnis Prodi Kewirausahaan, vol. 2, no. 1, pp. 200-213, 2020.

[4] F. A. Irfannudin and A. U. Hamdani, "Implementasi Sistem E-Commerce Pada Guna Motor Berbasis Content Management System (Cms) Wordpress," I D E a L I S, vol. 3, pp. 42-48, 2020.

[5] M. Hayaty and D. Meylasari, "Implementasi Website Berbasis Search Engine Optimization (SEO) Sebagai Media Promosi," J. Inform., vol. 2, pp. 295-300, 2018.

[6] W. Prabowo and J. Sutrisno, "PERANCANGAN E-COMMERCE UNTUK PENJUALAN SPAREPARTS PADA BENGKEL ABM MOTOR,” J. IDEALIS, vol. 2, pp. 74-80, 2019.

[7] F. Ramadhan and L. Fajarita, "Implementasi Rancangan E-Commerce Pada Surya Timur Collection Dengan Metode Business Model Canvas (Bmc) Berbasis Content Management System (Cms)," J u r $n$ a l I D E A L I S, vol. 3, no. 1, pp. 251-259, 2020.

[8] K. Y. Abdul Azis, Nurul Fuat, “Aplikasi Jadwal Event Cb Sejawa Timur Berbasis Android,” Issn 2598-2249, vol. 1, no. 1, pp. 487-494, 2017.

[9] Budiman and A. Saefudin, "Perancangan Sistem Pakar Diagnosa Peyakit Menular Seks Menggunakan Metode Case Based Reasioning Dengan Teknik Forward Chaining Berbasis Mobile Android,” J. Tek. Inform. Univ. Majalengka, pp. 210-222, 2018.

[10] E. Revsie Akbar and H. Irawan, "Analisis dan Implementasi E-Commerce Menggunakan CMS Wordpress Pada Queenita Classic," J. Idealis, vol. 4, no. 1, pp. 107-116, 2021.

[11] Himawan, Arisantoso, and A. Saefullah, "Search Engine Optimization (Seo) Menggunakan Metode White Hat Seo Untuk Meningkatkan Peringkat Dan Trafik Kunjungan Website," Pros. SNATIF ke-4 Tahun 2017, pp. 783-790, 2017.

[12] E. D. Wawolumaya, D. L. Tampi, and J. J. Rogahang, "Analisis Strategi Pemasaran Dalam Upaya Meningkatkan Volume Penjualan Pada Rose Collection Manado," Productivity, vol. 1, no. 2, pp. 134-141, 2020. 